\title{
MET Mutation Analysis
}

National Cancer Institute

\section{Source}

National Cancer Institute. MET Mutation Analysis. NCI Thesaurus. Code C158917.

A procedure used to detect and identify mutations in the MET gene. 